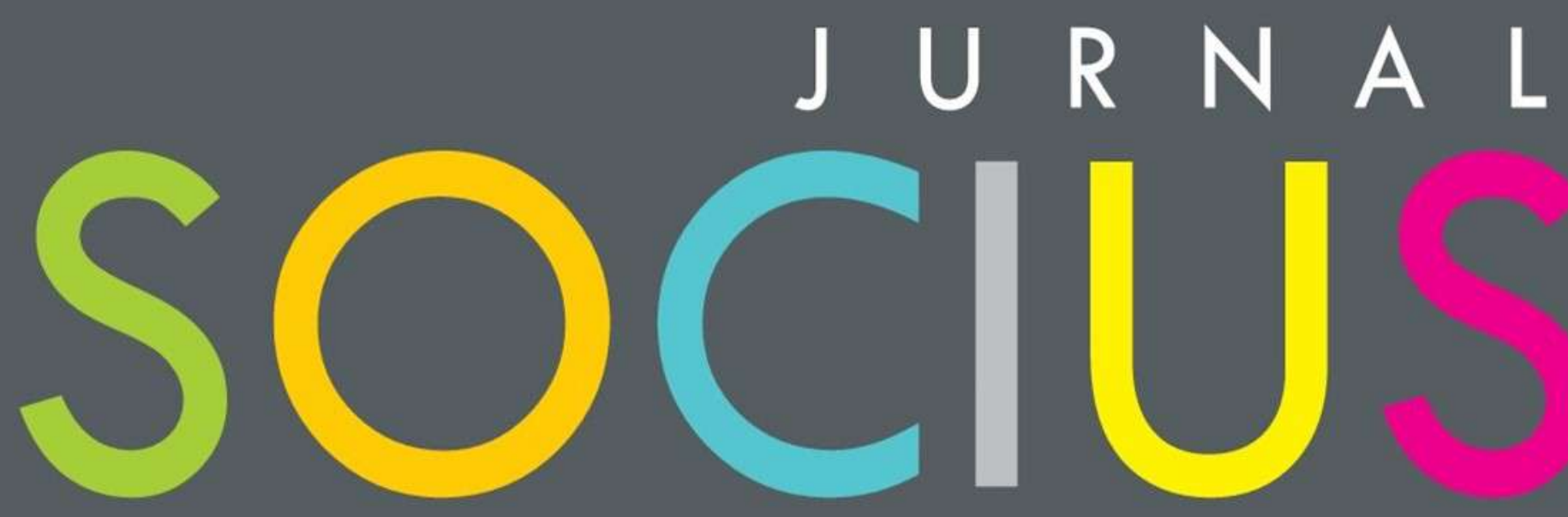

Journal of Sociology Research and Education

DITERBITKAN OLEH :

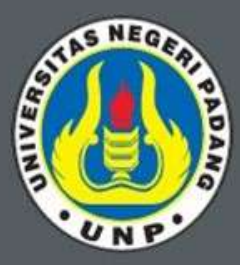

LABOR JURUSAN SOSIOLOGI FAKULTAS ILMU SOSIAL UNIVERSITAS NEGERI PADANG

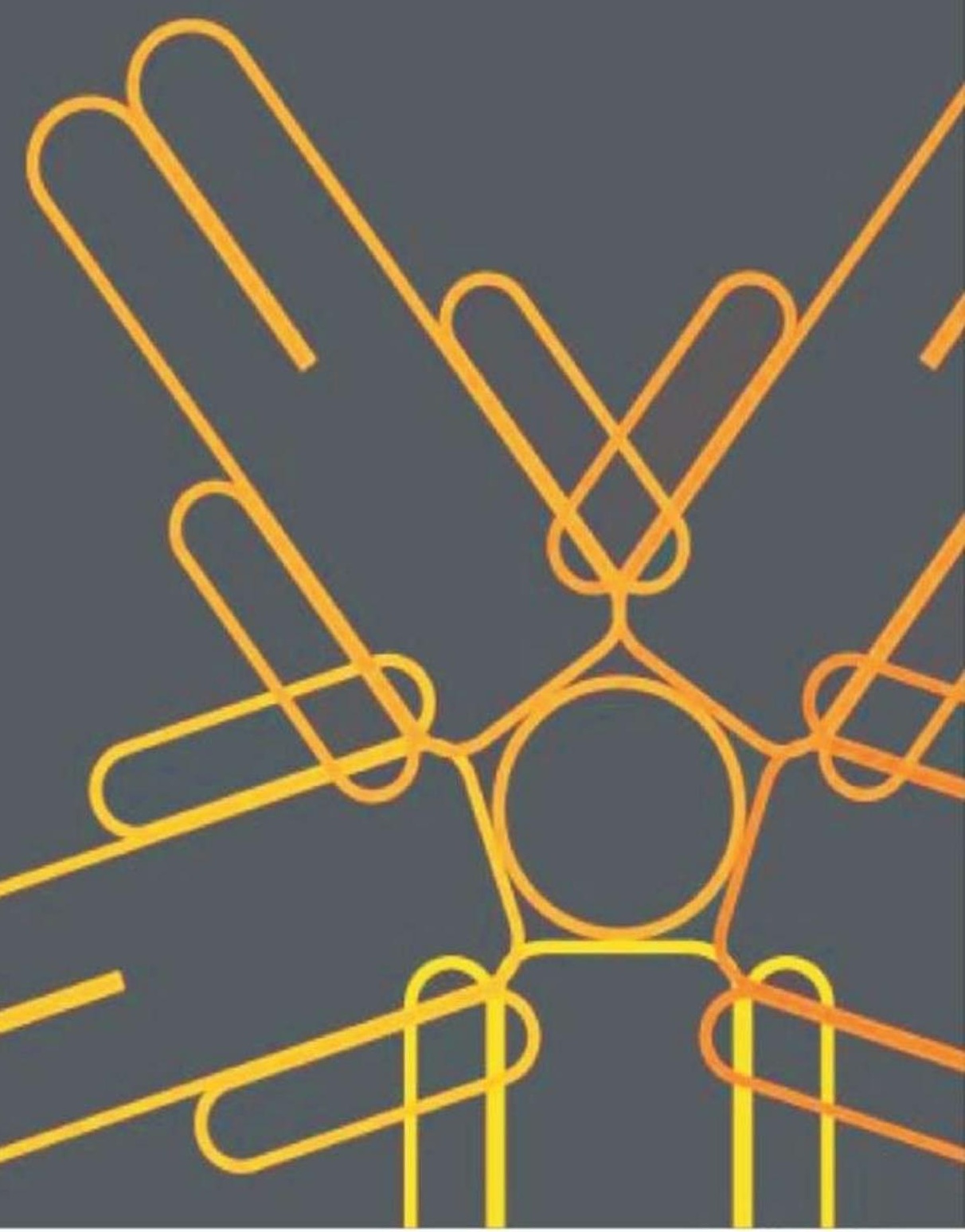




\section{SOCIUS}

Vol. 7, No. 1, Th. 2020

ISSN : 2356-4180 (cetak)

2442-8663 (online)

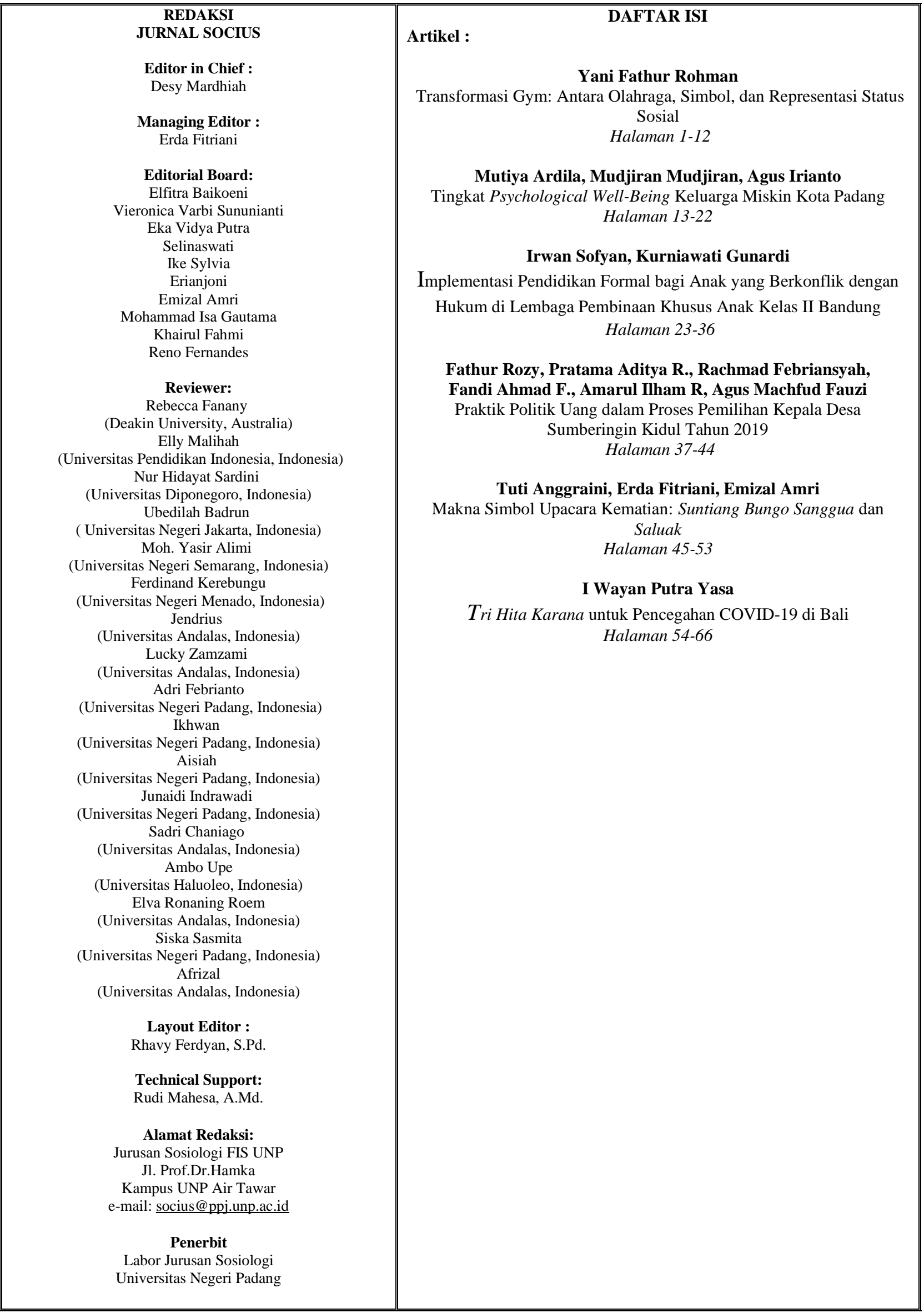




\title{
Transformasi Gym: Antara Olahraga, Simbol, dan Representasi Status Sosial
}

\author{
Yani Fathur Rohman
}

\author{
Universitas Indonesia
}

Email: yanifathur2.yf@gmail.com

\begin{abstract}
Abstrak
Studi tentang transformasi gym telah bergerak menuju sebuah gaya hidup dan pemanfaatan waktu luang. Penelitian ini bertujuan untuk mengeksplorasi keterkaitan aktifitas gym dan status sosial beserta dampak yang ditimbulkan dari rutinitas tersebut. Kajian-kajian sebelumnya terkait gym dalam prespektif ilmu sosial menyoroti dua hal diantaranya berbagai motivasi member bergabung dengan pusat kebugaran dan hiperealitas dalam transformasi pusat kebugaran. Kajian-kajian tersebut belum melihat berbagai upaya member dan dampaknya dalam membentuk dan mempertahankan status sosial melalui aktivitas gym. Metode kualitatif digunakan dan pengumpulan data diperoleh melalui observasi serta wawancara mendalam. Hasilnya, gym dimanfaatkan para member tidak hanya sekedar untuk berolahraga dan bodyshaping, tetapi juga untuk merepresentasikan posisi sosialnya di masyarakat. Berbagai fasilitas tambahan menjadi salah satu aspek yang menunjang member dalam memilih aktivitas waktu luangnya. Proses tersebut diperkuat dengan penggunaan aksesoris bermerek pusat kebugaran ke berbagai aktivitas lain dan pemanfaatan media sosial masing-masing. Dampaknya, upaya tersebut menimbulkan member mengalami penyimpangan realitas tentang diri dan penurunan tingkat well-being.
\end{abstract}

Keyword: Bodyshaping, Gym, Gaya hidup, Status social, Waktu luang

\section{Abstract}

Study about gym transformation have shifted toward a lifestyle and leisure time utilization. This study aims to explore the relevance of the gym activity and social status as well as its effects. Previous studies related to the gym in the social science perspective highlighted two things including the various motivations of member joining the fitness center and hypereality in the transformation of the fitness center. These studies have not yet focused on various members' efforts and their impact in shaping and maintaining social status through gym activity. Qualitative method is used with data collection obtained through observation and in-depth interview. As a result, the gym is used by members not only to exercise and bodyshaping, but also to represent their social position in the community. Various additional facilities become one of the aspects that support member in choosing their leisure time activity. The process is strengthened by the use of fitness center branded accessories to various other activities and the use of their respective social media. These efforts cause member to experience a distortion of reality about themselves and decrease the level of well-being.

Keyword: Bodyshaping, Gym, Lifestyle, Leisure time, Social status

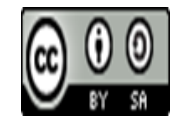

Received: April 15, 2020

Revised: June 10, 2020

Available Online: June 12, 2020

Jurnal Socius: Journal of Sociology Research and Education Vol. 7, No.1, Th. 2020

ISSN: Online 2442-8663 - Print 2356-4180

Copyright@2020, Jurnal Socius 


\section{Pendahuluan}

Gaya hidup sehat menjadi trend di kalangan remaja maupun dewasa untuk menghabiskan waktu luang mereka, termasuk menjadi anggota pusat kebugaran. Pada era kontemporer, masyarakat dihadapkan pada kondisi dimana menghabiskan waktu luang menjadi bagian yang dapat menggambarkan gaya hidup. Menurut Chaney (2006), siapapun yang hidup dalam masyarakat modern akan menggunakan gagasan tentang gaya hidup untuk menggambarkan tindakannya sendiri maupun orang lain termasuk dengan aktivitas konsumsi. Gaya hidup menjadi pola-pola tindakan yang membedakan antara satu orang dengan orang lain dimana budaya dan konsumsi memiliki peran sentral (Giddens, 1991; Jameson, 1991; Lash \& Urry, 1987). Dalam konteks ini, industri budaya, new consumer, dan aktivitas waktu luang memainkan peran yang lebih signifikan (Featherstone, 1991:164). Waktu luang sendiri merupakan kegiatan yang mana seseorang akan mengikuti keinginannya sendiri baik untuk beristirahat, menghibur diri sendiri, menambah pengetahuan atau mengembangkan keterampilannya secara objektif atau untuk meningkatkan keikutsertaan dalam bermasyarakat setelah ia melepaskan diri dari pekerjaannya, keluarga, dan kegiatan sosial (Torkildsen, 1992).

Pergeseran gym dari konsumsi para binaragawan untuk kepentingan kompetisi dan olahraga menjadi konsumsi publik dapat dilihat sebagai transformasi pusat kebugaran untuk memenuhi wacana gaya hidup sehat. Pada awal 1900-an, gym menjadi aktivitas mewah sebagai olahraga dan budaya fisik, namun secara bertahap menjadi perhatian bukan hanya bagi kaum aristokrasi dan binaragawan, tetapi juga para pekerja dan kelompok menengah (Andreasson \& Johansson, 2014). Gym sebagai gaya hidup kemudian menyebar dalam skala global menjadi konsumsi masyarakat banyak. Pusat kebugaran terus berkembang menjadi tempat yang mana unsur feminitas dan maskulinitas terus direproduksi. Agar digunakan sebagai objek untuk menjual berbagai hal, tubuh harus dibangun ulang oleh pemiliknya dan dilihat secara narsistik ketimbang secara fungsional (Piliang, 2011). Misalnya, majalah Muscle \& Fitnessnya terjual lebih dari 400.000 kopi pada pertengahan 1970-an. Pada saat yang sama, Gold's Gym yang terkenal berkembang dari gym kecil menjadi waralaba global yang kuat termasuk di Indonesia (Liokaftos, 2012). Peningkatan minat masyarakat terhadap industri kebugaran juga tidak terlepas dari pertumbuhan dan pergeseran gaya hidup masyarakat Indonesia. Pergeseran dalam arti kemunculan tren gaya hidup sehat, serta semakin pedulinya masyarakat atas pentingnya penampilan fisik (Wijayanti, 2009).

Gold's Gym menjadi satu dari dua nama besar pusat kebugaran di Indonesia yang mendapat beragam penghargaan diantaranya top brand award untuk bisnis kebugaran tahun 2010, 2012, dan 2014 serta tersebar di kota-kota besar termasuk di Surabaya Town Square. Pusat kebugaran ini telah memiliki lebih dari tiga ribu member dan fasilitas yang kompleks termasuk sauna (diakses melalui http://Gold'gymIndonesia.co.id. 07/032015). Kurniasari (2016) dalam penelitiannya berjudul hiperealitas dalam transformasi eksistensi pusat kebugaran menemukan bahwa transformasi pusat kebugaran disebabkan beberapa faktor diantaranya pengaruh budaya popular, media, dan pergaulan. Tidak semua member pusat kebugaran berstatus sebagai "real shopper" atau menjadikan gaya hidup sehat sebagai kebutuhan jasmani, kebutuhan utama mengikuti fitness, tetapi terdapat unsur "socialize shopper" yang mana pengaruh untuk bersosial dan mengikuti tren juga memiliki pengaruh yang signifikan (Kurniasari, 2016). Aktivitas kebugaran secara terus menerus telah direnovasi bukan hanya sebagai olahraga, tetapi mampu menjadi budaya popular bagi kaum urban (Sassatelli, 2016). Hal ini selaras dengan karjian Bordieou (1978) yang menemukan 
keterkaitan antara kelas sosial dan gaya hidup (Stempel, 2000). Bukti keterkaitan kelas sosial dan gaya hidup diperkuat dengan penelitian yang menemukan bahwa status sosial ekonomi orang tua dapat menentukan jenis-jenis olahraga yang dilakukan anak-anaknya dan peningkatan partisipasi pada aktivitas fisik untuk mengisi waktu luang (Felipe, Henrique, \& Monteiro, 2012).

Penelitian lain tentang studi motivasi berolahraga di pusat kebugaran pada wanita di Kota Surakarta menemukan bahwa aspek kesenangan mendominasi daripada aspek kesehatan. Sebagian besar wanita anggota pusat kebugaran melakukan aktivitas ngegym dengan tujuan untuk bersenang-senang dan mendapat kegembiraan untuk kebanggaan (Indriyana, 2014). Lebih jauh, mengikuti trend berolahraga di pusat kebugaran yang berada di mall berpengaruh signifikan terhadap harga diri dan aktualisasi diri seseorang. Terdapat kebanggaan menjadi bagian dari orang-orang kota dengan gaya hidupnya yang dianggap modern (Gurusinga, 2015). Sedangkan penelitian lain menemukan bahwa gym bukan hanya tempat anak-anak muda melakukan latihan, tetapi juga menjadi ruang sosial dimana identitas gender dikontruksikan (Johansson, 1994). Terjadi proses "feminization" dari budaya gym bagi kaum perempuan dengan menolak apa yang disebut dengan "dirty weight". Hal ini dikonfirmasi oleh penelitian Wheaton (2003) tentang "Body Projects and the Regulation of Normative Masculinity" menemukan bahwa wacana tentang pusat kebugaran dioperasikan sebagai penataan seperangkat ide yang bekerja bersama untuk membangun makna, sekaligus upaya untuk memodifikasi penampilan tubuh. Lebih jauh, mereka mengungkapkan bagaimana tubuh pria dimasukkan ke dalam jaringan norma dan hubungan sosial yang kompleks. Wacana gaya hidup sehat dengan menjadi member pusat kebugaran kemudian menjadi rancuh. Terdapat ketidakselarasan antara esensi dengan realita dalam praktiknya.

Maraknya bisnis kebugaran menimbulkan persaingan yang cukup tinggi. Hal tersebut membuat pengusaha memperhatikan rencana strategi yaitu dengan cara menambah usaha baru, dengan cara diversifikasi terhadap produk perusahaan selain produk jasa layanan latihan kebugaran, dan menambah fasilitas jasa layanan kebugaran yang menyenangkan (Panigoro, 2013). Transformasi layanan yang diberikan pusat kebugaran semakin mengukuhkan gym sebagai gaya hidup dan pemanfaatan waktu luang dengan menikmati layanan sekunder yang diberikan. Ini menjadi baukti bahwa kapitalisme telah memperluas kekuasaannya dari ranah kerja ke dalam ranah waktu luang (Fhiske, 2006). Pergeseran pusat kebugaran dari olahraga menjadi gaya hidup berpotensi merubah tatanan kelas sosial masyarakat. Globalisasi telah memunculkan kelas sosial baru melalui berbagai sarana dimana orang dapat menunjukkan status sosialnya dari kebiasaan dalam memanfaatkan waktu luang (Veblen, 1994). Di era modern, dalam suatu masyarakat termiskin sekalipun, mereka tetap ingin melakukan aktifitas konsumsi yang baik untuk mempertahankan maupun menunjukkan self-esteem dan posisinya di tengah masyarakat atau Veblen merujuk aktivitas ini sebagai "Waste". Istilah tersebut juga disinggung oleh Bordieou sebagai konsumsi budaya dengan tujuan yang tidak lain berupa simbol (Trigg, 2016). Konsumsi menjadi bagian yang tak terpisahkan dari penciptaan gaya hidup. Gaya konsumsi termasuk jasa yang dimuati dengan nilai tanda dan makna simbolik tertentu, yang membentuk apa yang disebut gaya hidup konsumerisme (Piliang, 2011).

Kajian-kajian terkait gym sebagai gaya hidup dapat dikatagorikan ke dalam dua subtansi. Pertama membahas mengenai ruang dalam mereproduksi maskulinitas dan feminitas (Johansson, 1994; Wheaton, 2003). Kajian-kajian ini melihat pusat kebugaran sebagai sarana untuk melanggengkan budaya patriarki dan disiplin tubuh mengenai sosok laki-laki dan perempuan yang ideal. Kedua, fokus pada motivasi member bergabung pada 
pusat kebugaran. Kajian-kajian ini menyoroti dua hal utama yakni upaya gaya hidup sehat dan representasi identitas sebagai bagian dari budaya popular dan konsumerisme (Gurusinga, 2015; Indriyana, 2014; Kurniasari, 2016). Pusat kebugaran di satu sisi masih menjadi primadona untuk membiasakan diri untuk hidup sehat dengan berolahraga. Namun di sisi lain, beberapa penelitian menemukan bahwa pusat kebugaran bergerak semakin jauh dari esensinya dengan mengarusutamakan layanan sekunder dan berbagai fasilitas tambahan untuk kenyamanan, bukan hanya sekedar berolahraga.

Kajian-kajian sebelumnya banyak melihat pusat kebugaran sebagai simbol budaya popular, tetapi belum melihat keterkaitannya dengan waktu luang, dan kelas sosial. Penelitian ini akan mengeksplorasi keterkaitan antara Gold's Gym sebagai pusat kebugaran, pemanfaatan waktu luang, dan mobilisasi kelas sosial. Semakin beragamnya industri waktu luang berdampak pada munculnya kelas-kelas baru di masyarakat. Pentingnya aktivitas waktu luang yang mencolok tidak hanya terletak pada pembangunan sistem perbedaan simbolik, tetapi pertama-tama sebagai komunikasi mendasar untuk perbedaan kelas, dan perjuangan untuk mendapatkan posisi sosial yang lebih tinggi (Veblen, 1994). Peniruan gaya hidup melalui aktivitas waktu luang kemudian dapat dilihat sebagai konsekuensi dari pendistribusian kekayaan yang tidak merata. Di sisi lain sebagai bentuk pencarian status sosial, pengakuan masyarakat melalui aktivitas waktu luang yang mentereng.

Kerangka konseptual Veblen mengenai "The Leisure Class" digunakan dalam analisa penelitian ini. Kerangka ini melihat cara individu memainkan status sosialnya. Bagi Veblen, waktu luang bukan menjadi suatu hal yang netral, benda mati yang tidak merepresentasikan apapun. Aktivitas waktu luang mampu menunjukkan posisi sosial seseorang juga sarana mobilisasi kelas (Veblen, 1994). Aktivitas tersebut dapat dilihat sebagai salah satu bentuk konsumsi. Konsumerisme memanipulasi pengalaman emosional dan mengeksplorasi diri yang mungkin, sebagai fenomena kapitalis, tidak dapat dipahami hanya sebagai kebiasaan konsumsi yang mencolok (Varul, 2006). Standar hidup masyarakat modern telah megontrol masyarakat dalam hal konsumsi dimana pencapaian standar hidup diiringi dengan pengakuan masyarakat terhadap posisi dirinya, aktivitas konsumsi waktu luang berbanding lurus dengan pencapaian stratifikasi sosial. Konsumsi ini sekaligus menjadi sebuah rutinitas untuk menjaga tradisi sebagai masyarakat modern. Kebiasaan konsumtif dalam memanfaatkan waktu luang disadari sebagai aktifitas yang negatif, tetapi seseorang bertindak hampir semata-mata untuk mencegah berhenti dari skala pengeluaran yang mencolok yang telah menjadi kebiasaan dan ketakutan akan kehilangan status sosial (Veblen, 1994).

Kelompok ini kemudian disebut Veblen sebagai "Leisure Class", kelompok orangorang yang sibuk mempertahankan status sosialnya ataupun orang-orang kelas menengah kebawah yang tidak ingin ditendensikan sebagai kelas bawah yang menjadikan waktu luang sebagai representasi dirinya. Untuk menjadi lebih disegani daripada yang lain justru kemampuan konsumsi pada sesuatu yang dianggap paling tidak diperlukan (Veblen, 1994). Di sisi lain menunjukkan kemampuannya dalam mengkonsumsi produk-produk tersebut yang tidak bisa diakses semua orang. Terdapat kecenderungan kelas bawah untuk menyalin dan meniru "atasannya" sambil berusaha untuk maju secara sosial. Pada saat yang sama, kemajuan industri membuat barang yang digunakan untuk pembeda menjadi lebih murah. Ini merangsang dinamika di mana kelas yang ditiru mengembangkan pola konsumsi yang lebih mahal dan rumit untuk menjaga posisi sosial mereka.

Kerangka ini mengeksplorasi permainan status baik melalui konsumsi mencolok yang terdiri dari tampilan barang-barang konsumen yang mahal (conspicuous consumption) atau 
melalui tampilan terbuka dari kegiatan waktu luang (conspicuous leisure) (Varul, 2006). Di zaman modern, orang-orang yang menjadi member pelatihan olahraga-olahraga khusus, bodyshaping, telah menginvestasikan banyak waktu dalam memperoleh serangkaian keterampilan yang tujuan produktif utamanya adalah untuk mengesankan orang lain. Dengan terlibat dalam waktu senggang yang mencolok, orang-orang ini melakukan pertukaran secara sadar (Frijters \& Leigh, 2008). Salah satu cara adalah liburan yang menyenangkan, bersantai di tempat-tempat terbuka. Kategori ini termasuk kegiatan tanpa fungsi yang nyata, di banding dengan waktu luang untuk mempersiapkan hal tersebut.

Konsep ini menekankan bahwa utilitas satu orang jatuh ketika pendapatan orang-orang dalam kelompok referensi meningkat. Prediksi ini telah menjadi subjek perdebatan empiris yang intens dalam literatur well-being. Di satu sisi Conspiciuous consumption dapat menjadi strategi sosial yang menguntungkan karena tampilan mewah yang mencolok menjadi sinyal eksklusif yang memunculkan perlakuan menguntungkan yang bergantung pada status dalam interaksi sosial manusia (Nelissen \& Meijers, 2011). Di sisi lain, kebiasaan konsumsi dan aktivitas waktu luang dapat berkosenkuensi pada penurunan tingkat kebahagiaan individu dan self-esteem (Varul, 2006). Self-esteem menjadi cerminan seseorang untuk diterima dalam kelompok sosial. selain memberikan kesan positif, upaya untuk diakui secara sosial melibatkan penyimpangan realitas tentang diri sendiri (Leary \& Baumeister, 2000). Ini menjadi alasan kenapa conspicuous leisure and conspicuous consumption disadari sebagai kebiasaan negatif tetapi sulit ditinggalkan. Masyarakat bergantung pada aktivitas konsumsi untuk meraih kebahagiaan. Pada saat yang sama, yang mengeksploitasi adalah simbol yang berfungsi sebagai tanda pembeda diantara kelas-kelas yang ada (Veblen, 1994). Sesuai dengan skema yang ideal bagi kehidupan masyarakat. Konsumsi seperti terkait dengan pekerjaan mereka merupakan sarana untuk melakukan kegiatan lanjutan, dan bukan konsumsi yang diperlukan. Hal tersebut hanya sebagai tanda kecakapan dan penghasilan tambahan bagi derajat manusia, barang-barang sekunder menjadikan dirinya terhormat, terutama konsumsi hal-hal yang lebih diinginkan (Veblen, 1994).

Konsep ini akan mengeksplorasi keterkaitan transformasi olahraga gym sebagai gaya hidup dengan peran pusat kebugaran dalam membentuk status sosial indvidu. Pusat kebugaran dapat dilihat sebagai conspicuous leisure, sekaligus conspicuous consumption. Bagaimana rutinitas sebagai member gym merupakan aktivitas yang bukan hanya menunjukkan gaya hidup sehat, tetapi lebih dari itu terdapat pertunjukan status, melalui aktivitas pemborosan waktu luang yang Veblen menyebutnya sebagai "waste", juga konsumsi tanda. Pergeseran gym sebagai olahraga menjadi gaya hidup memiliki konekusensi besar bukan hanya terkait kebiasaan, tetapi pengakuan akan status sosial individu di tengah masyarakat.

\section{Metode Penelitian}

Penelitian ini merupakan penelitian kualitatif dengan pendekatan studi kasus pada member Gold's gym Surabaya Town Square. Penelitian ini menelaah kasus mengenai keterkaitan aktifitas gym dan status sosial beserta dampak yang ditimbukan dari rutinitas tersebut dalam konteks atau setting kehidupan kontemporer dengan menggunakan beragam sumber informasi diantaranya wawancara, berbagai laporan, dan dokumen (Creswell, 2002). Sedangkan pusat kebugaran ini dipilih karena menjadi salah satu pusat kebugaran di dunia termasuk di Indonesia. Penelitian ini memberikan data mengenai gaya hidup ngegym dengan berbagai aspek sosial yang mendorong masyarakat untuk bergabung dengan pusat kebugaran 
ternama. Informan dari penelitian ini terdiri dari enam orang yang terdiri dari manager perusahaan, tiga member laki-laki dan dua member perempuan. Manejer dipilih untuk memberikan informasi tentang dinamika perusahan. Untuk mengetahui keterkaitan gym dengan berbagai aspek sosial yang mendorong masyarakat untuk bergabung, peneliti melakukan wawancara mendalam dengan membernya, serta memilih laki-laki dan perempuan untuk menghindari adanya bias gender. Pengumpulan data dilakukan dengan observasi secara berkala dan wawancara mendalam. Wawancara dilakukan dengan menyesuaikan waktu luang para informan.

\section{Hasil dan Pembahasan}

\section{Transformasi Fungsi Ngegym}

Gym sebagai gaya hidup semakin tidak terelakkan dengan meningkatnya jumlah member pusat kebugaran dari tahun ke tahun. Gym atau fitness menjadi gaya hidup yang banyak diminati seiring dengan wacana gaya hidup sehat. Namun temuan di lapangan menunjukkan alasan utama untuk menjadi member gym adalah mengisi waktu luang, rileksasi, dan bodyshaping. Beberapa informan mengungkapkan bahwa aktivitas "ngegym" untuk mengisi kejenuhan mereka di tengah aktivitasnya kesehariannya. Terdapat kecenderungan bahwa informan laki-laki memiliki motivasi keikutsertaannya sebagai aktivitas waktu luang dan keinginannya dalam menambah masa otot tubuh. Sedangkan informan perempuan menekankan kenyamanan dari fasilitas-fasilitas rileksasi yang disediakan dan keinginannya memiliki bentuk tubuh yang ideal. Hal ini mengkonfirmasi penelitian-penelitian sebelumnya bahwa sebagian besar wanita anggota pusat kebugaran melakukan aktivitas ngegym dengan tujuan untuk bersenang-senang dan mendapat kegembiraan untuk kebanggaan (Indriyana, 2014; Kurniasari, 2016).

Aspek feminitas dan maskulinitas tidak terlepas dari motivasi member bergabung dengan pusat kebugaran. Pusat kebugaran sebagai sarana dalam melanggengkan, dan mendisiplinkan tubuh ditemukan dalam penelitian ini. Temuan ini sekaligus menguatkan hasil penelitian-penelitian sebelumnya bahwa pusat kebugaran memiliki peran dalam mengkontruksi bentuk tubuh ideal yang bias akan gender (Andreasson \& Johansson, 2014; Johansson, 1994; Wheaton, 2003). Hal ini diperkuat dengan berbagai jenis penawaran promo salah satunya promo The Avenger. Perusahaan memanfaatkan film-film box office yang juga merepresentasikan power bagi tokoh laki-laki dan komodifikasi tubuh bagi tokoh-tokoh perempuan. Seolah-olah mensugestikan jika menjadi member Gold's Gym akan membuat mereka memiliki bentuk tubuh seperti yang ada di karakter film tersebut. Hal ini disampaikan oleh salah satu membernya, "ada promo gara-gara ada film Avenger itu jadi dapat aksesorisnya, tas gitu-gitu' (Informan R, wawancara 20 Mei 2015). Melalui temuan tersebut, dapat dilihat bahwa pusat kebugaran sudah bergerak jauh dari esensinya, dari wacana yang berkembang tentang gaya hidup sehat. Penekanan pada bodyshaping dan layanan sekunder kemudian menggagalkan wacana fitness sebagai gaya hidup sehat. Hal ini menimbulkan pertanyaan, misalnya apakah hidup sehat harus memiliki otot-otot yang kekar dan memiliki tubuh yang sexy? Apakah yang membuat tubuh sehat itu alat-alat olahraganya ataukah fasilitas rileksasi yang lain?. Seperti yang diungkapkan Ade Rai (2009) pada bukunya yang berjudul "Tingkatkan Fitness IQ Anda" yaitu "fitnes adalah gaya hidup sehat memiliki tiga elemen dasar yakni olahraga teratur, nutrisi teratur dan istirahat teratur". Hal tersebut mengindikasikan bahwa sebenarnya mengikuti gaya hidup sehat lebih pada keseimbangan (balance) antara olahraga, makan, dan istirahat secara teratur. Sehingga tidak diragukan jika 
terdapat keterkaitan erat transformasi pusat kebugaran, gaya hidup, dan eksistensi, serta kapitalisasi. Fakta ini menegaskan pernyataan Veblen bahwa kapitalisme telah bergerak dari ranah konvensional ke dalam bisnis-bisnis waktu luang (Veblen, 1994).

Di sisi lain, eksistensi dapat dilihat tidak hanya dari aktivitas bodyshaping yang dilakukan, dengan menonjolkan aspek maskulinitas dan feminitas, tetapi lebih jauh ke ranah penegasan posisi sosial di tengah-tengah masyarakat. Kebutuhan untuk diakui secara sosial dengan menjadi member pusat kebugaran tampak terlihat ketika ngegym lebih dinilai sebagai gaya hidup untuk mengisi waktu luang, bukan lagi untuk berolahraga dan menjalankan gaya hidup sehat. Fakta dilapangan mayoritas dari informan lebih menekankan fasilitas-fasilitas sekunder yang disediakan sebagai daya tarik utama. Salah satunya mengatakan sebagai berikut:

"Selesai olahraga, kita itu bisa mengeluarkan banyak keringat, pastinya. Tetapi ada fasilitasnya yang kayak gitu-gitu tadi, jacuzzi, sama sauna jadi bikin kita santai, nyaman. Kalau olahraga aja diluar juga bisa, tapi kan beda (Informan R, wawancara 20 Mei 2015)".

Secara tidak langsung, unsur pembeda dari pusat kebugaran tersebut telah disinggung oleh informan. Apa yang disebut sebagai 'pembeda' tersebut mengindikasikan dua hal penting. Pertama, aktivitas olahraga yang dilakukan di tempat tersebut bukan sekedar olahraga, tetapi kenyamanan. Kedua, memperlihatkan tidak semua orang bisa mengakses olahraga ditempat tersebut. Sehingga menghabiskan waktu luang di tempat tersebut menjadi salah satu aspek untuk menegaskan bahwa individu tersebut layak disegani karena rutinitasnya yang mengandung previlage. Dengan terlibat dalam waktu luang yang mencolok, orang-orang ini melakukan pertukaran secara sadar. Ketika orang-orang di lingkungannya mengenal seseorang memiliki rutinitas waktu luang yang tidak semua orang bisa melakukan. Pada saat bersamaan, hal ini melegitimasi status sosialnya di tengah masyarakat berkaitan dengan bagaimana orang-orang harus memperlakukan mereka. Sehingga, Gold's Gym menjadi sarana pemanfaatan waktu luang sekaligus sebagai penegasan status sosial seseorang.

\section{Gym sebagai Representasi Status Sosial dan Dampaknya Terhadap Self-esteem}

Konsumsi waktu luang dengan aktivitas gym merupakan kebutuhan sekunder bagi mahasiswa karena pada dasarnya menjaga kesehatan dan kebugaran tidak harus ke pusat kebugaran yang mewah bahkan bisa dilakukan dengan melakukan olahraga lain dengan biaya yang jauh lebih murah. Namun, bagi beberapa kelompok gaya hidup dalam memanfaatkan waktu luang menjadi bagian yang tak terpisahkan dari self-esteem. Kemampuan memanfaatkan waktu luang dengan aktivitas-aktivitas yang menyenangkan, santai, membutuhkan banyak waktu dan juga materi berbanding lurus dengan semakin tingginya self-esteem yang dimiliki. Dengan kata lain, hal ini membuatnya lebih terhormat, setingkat lebih tinggi daripada mereka yang menghabiskan waktu luang dengan olahraga seperti joging, atau fitness di tempat-tempat yang tidak banyak memakan biaya. Untuk menjadi lebih disegani daripada yang lain, individu justru harus menunjukkan kemampuan konsumsi pada sesuatu yang dianggap paling tidak diperlukan.

Semua informan memberikan pandangan mengenai alasan pemilihan Gold's Gym secara spesifik, selain karena kenyamanan dan beragam fasilitas tambahannya juga karena Gold's Gym sendiri yang dikenal sebagai pusat kebugaran yang mewah dan prestisius. Ingin ditekankan bahwa mereka menjadi bagian dari pusat kebugaran yang bergengsi. 'kalo di 
tempat kecil setahuku cuma buat ngegym aja, gak ada kelas-kelasnya, malu juga ikut di tempat seperti itu' (Informan S, wawancara 21 Mei 2015). Fakta ini mengisi kekosongan pada penelitian-penelitian sebelumnya yang hanya melihat pusat kebugaran sebagai sara untuk mereproduksi maskulinitas dan feminitas. Terdapat kecendrungan lain bahwa mereka cukup memperhatikan dimana seharusnya dirinya berolahrga juga menghabiskan waktu luang. Tempat menjadi aspek yang memuat simbol tertentu dan untuk siapa seharusnya ruang tersebut dikonsumsi. Penekanan pada kelas-kelas tertentu sebagai bagian dari layanan pusat kebugaran menjadi komponen yang dapat dijadikan pembeda sejauh mana kemampuan seseorang dapat mengakses layanan tersebut. Ini menunjukkan bahwa seseorang sangat memperhitungkan tempat-tempat yang dapat menggambarkan status sosialnya, serta tidak ingin menghabiskan waktu luang di tempat yang justru membuat orang melihat lebih rendah. Di era modern, orang-orang yang menjadi member pelatihan olahraga-olahraga khusus, bodyshaping, telah menginvestasikan banyak waktu dalam memperoleh serangkaian keterampilan yang tujuan produktif utamanya adalah untuk mengesankan orang lain.

Gaya hidup dengan menonjolkan aktivitas waktu luang pada dasarnya menjadi ciri khas masyarakat modern terutama bagi mereka yang memiliki kelebihan finansial. Mereka memiliki kebutuhan untuk mencari pembeda dengan kelompok lain. Di sisi lain, gaya hidup yang demikian sudah menjadi tradisi dan warisan keluarga. Salah satu informan menekankan bahwa menjadi member pusat kebugaran seperti sudah menjadi kewajiban bagi seluruh anggota keluarga. Bahkan, olahraga yang diikuti tidak hanya fitness tetapi juga golf. "'saya sudah biasa dialokasikan uang segini untuk makan, segini olahraga, keluarga saya semua seperti itu" (informan G, wawancara 21 Mei 2015). Terdapat dua kelompok yang memiliki kebiasaan memanfaatkan waktu luang dengan aktivitas yang mencolok. Pertama seperti informan di atas, yang mana mereka memanfaatan pusat kebugaran menjadi sarana untuk mempertahankan status sosial disamping olahraga. Di satu sisi, tidak ada yang terlalu dikhawatirkan dari kelompok ini selain pertunjukan ketimpangan sosial dari distribusi ekonomi yang tidak merata. Semua anggota keluarga memiliki keharusan mentaati gaya hidup untuk merepresentasikan posisi sosial seseorang. Ini menjadi apa yang disebut Veblen sebagai bentuk konsumsi yang diwakilkan.

Kedua, kelompok yang sedang berupaya meningkatkan self-esteem untuk lebih disegani di tengah masyarakat. Waktu luang menjadi sarana bukan untuk mempertahankan status sosianya, tetapi menunjukkan mereka sedang bergerak menuju kelas sosial yang lebih baik, lebih dihormati. 'kalau disini kesan gaulnya dapat mas, wih anak gym' (Informan A, wawancara 27 Mei 2015). Terdapat kecenderungan kelas bawah untuk menyalin dan meniru atasannya sambil berusaha untuk maju secara sosial. Kecemasan menjadi dampak ketika kelompok ini tidak menjalani rutinitas waktu luangnya dengan aktivitas ngegym di Gold's Gym. Salah satu informan mengungkapkan hal ini. "'aku pernah coba berhenti, gak sampe dua minggu gak enak banget rasanya, karena gak olahraga iya, tapi lebih gak enak pas ditanyai temen-temen" (Informan S, wawancara 15 Mei 2015). Keterangan tersebut menunjukan penurunan self-esteem ketika individu berhenti dari rutinitas waktu luangnya. Dengan kata lain, kebiasaan konsumsi dan aktivitas waktu luang dapat berkonsekuensi pada penurunan tingkat kebahagiaan individu. Mereka kehilangan sarana untuk memainkan status sosial dan representasi diri di tengah masyarakat. Seseorang bertindak hampir semata-mata untuk mencegah berhenti dari skala pengeluaran yang mencolok yang telah menjadi kebiasaan dan ketakutan akan kehilangan status sosial (Veblen, 1994). 
Rutinitas waktu luang dengan ngegym di pusat kebugaran yang cukup mahal serta menawarkan berbagai fasilitas lebih kemudian menjadi kerangkeng bagi kelompok masyarakat yang memanfaatkan untuk meningkatkan posisi sosialnya. Ketakutan dan kecemasan menjadi konsekuensi dari keputusannya bergabung sebagai member di tempat tersebut jika sewaktu-waktu mereka lebih ingin memprioritaskan kebutuhan lain yang lebih penting. Temuan ini melengkapi kerangka Veblen tentang konsep the leisure class. Leisure class bukan hanya memanfaatkan waktu luangnya untuk representasi kelas sosial mereka, dan karena itu aktivitas tersebut harus dipertahankan, tetapi efek lain jika aktivitas tersebut tidak dipertahankan adalah penurunan self-esteem individu yang membuat interaksi dengan kelompok sosialnya terganggu. Artinya individu tidak hanya kehilangan status sosialnya, tetapi juga keterlekatan dengan kelompok sosialnya menjadi renggang. Oleh sebab itu, gaya hidup dengan menonjolkan aktivitas waktu luang tidak hanya dapat dilihat sebagai fenomena olahraga, tetapi memiliki konsekuensi pada aspek psikologi dan sosial.

\section{Sosial Media sebagai Alat Representasi Status Sosial}

Pusat kebugaran Gold's Gym menawarkan banyak fasilitas serta ketenaran namanya membawa kebanggaan tersendiri bagi membernya. Member tidak hanya rutin datang ke Gold's Gym tetapi seringkali mencari media lain untuk membantu memperlihatkan aktivitas fitnessnya. Sebagai pusat kebugaran yang mewah dan prestisius, terdapat beragam tanda atau simbol yang dapat diakuisisi para member untuk semakin menegaskan mereka menjadi bagian dari salah satu pusat kebugaran paling bergengsi di Indonesia. Seiring dengan adanya media sosial, hal tersebut menjadi sarana untuk menunjukkan tidak hanya apa yang sedang dikonsumsi, tetapi juga menunjukkan tempat dimana kebiasaan seseorang melakukan aktivitas. Dari media sosial ini, seseorang dapat menunjukkan kepada kelompok sosialnya bahwa ia pantas disegani karena aktivitas konsumsi yang tidak semua orang dapat mengaksesnya. Hal ini dilakukan member dengan aktif di media sosial mereka ketika ngegym, berbagi story dan tempat dimana dirinya melakukan aktivitas tersebut. Mayoritas informan mengungkapkan kegemarannya dalam berbagi aktivitas ngegym di media sosial. "Iya, paling story di IG kalau uploud jarang" (wawancara informan R 20 Mei 2015). Hal yang sama juga dikatakan informan S. "sering kalau share di medsos, hampir tiap ngegym" (informan S, wawancara 15 Mei 2015).

Keterangan tersebut menggambarkan adanya keterkaitan media sosial dengan pemilihan tempat dalam memanfaatkan waktu luang. Terdapat usaha menampilkan segala bentuk konsumsinya ke publik untuk menunjukkan bahwa karena aktivitasnya, ia pantas di segani. Temuan ini mengkonfirmasi bahwa masyarakat bergantung pada aktivitas konsumsi untuk meraih kebahagiaan. Pada saat yang sama, yang mengeksploitasi adalah simbol yang berfungsi sebagai tanda pembeda diantara kelas-kelas yang ada. Media sosial seperti halnya instagram, dalam hal ini memiliki hubungan yang erat dengan self-esteem karena mampu menjadi sarana baru dalam menunjukkan status sosial seseorang. Hal ini dapat dilihat melalui kebiasaan aktivitas konsumsi yang di share ke media sosial. Adanya media sosial juga mempermudah seseorang jika ingin menunjukkan keberadaannya dalam melakukan aktivitas konsumsi. Dari postingan-postingan di media sosial tersebut, kelompok sosialnya akan menilai posisinya di tengah masyarakat. Dengan menunjukkan aktivitasnya di Gold's Gym dan di share ke media sosial akan membantu seseorang untuk menghindari justifikasi bahwa ia termasuk lower class. Dirinya termasuk ke dalam kelompok masyarakat yang mampu melakukan aktivitas konsumsi yang eksklusif. 
Secara tidak langsung, hal ini juga menjadi salah satu faktor mengapa member mempertahankan kebiasaan ngegymnya. Tingginya tingkat konsumsi pada masyarakat modern dapat dipertahankan terutama oleh kekuatan dari kebiasaan dan hal itu disadari sebagai sesuatu yang tidak mudah untuk ditinggalkan karena sudah menjadi rutinitas. Kebiasaan yang sudah tertanam pada tahap berikutnya akan membuat member rela mengeluarkan biaya yang cukup besar dan meluangkan waktunya untuk menikmati fasilitas kebugaran. Selain melalui media sosial, aksesoris brand fitness seperti tas juga menjadi simbol yang dapat menunjukkan dimana seseorang melakukan aktivitas konsumsi. Aksesoris ini dapat digunakan ketika melakukan aktivitas lain, sehingga dengan mudah kelompok sosial mengenali posisi sosialnya. Beragam aksesoris mereka dapatkan ketika proses pendaftara sebagai anggota seperti tas besar, kaos dan lain-lain yang bergambarkan logo Gold's gym. Aksesoris ini menjadi penunjang bagi member di satu sisi memperkenalkan aktivitas konsumsi waktu luangnya, di sisi lain membuat self-esteem mereka meningkat, membuat mereka jauh lebih percaya diri ketika membawa atau memakainya. Perhatian dari kelompok sosial dan masyarakat pada umumnya yang mengerti tentang dunia fitnesss akan menambah poin penting untuk mengangkat prestise seseorang dan mendapat pengakuan bahwa ia setingkat lebih tinggi dari member pusat kebugaran yang lain. "Kan biasa pulang ngegym itu bebas terserah kan, biasanya kalo ke kampus gitu bawa tasnya sekalian kuliah biasanya, malu sih enggak, malah jadi bahan obrolan teman-teman" (Informan A, wawancara 27 Mei 2015).

Temuan ini menunjukkan terdapat setidaknya dua komponen bagaimana member tidak hanya sekedar berolahraga, tetapi juga ingin merepresentasikan status sosialnya. Pertama, yakni dengan rutin datang ke Gold's Gym dan sharing di media sosial. Hal ini karena media sosial menawarkan fitur untuk share location and activity yang dapat dengan mudah membuat banyak orang lebih mengetahui tempat dan aktivitas apa yang sedang dikerjakan seseorang. Seseorang dapat mengetahui seberapa banyak orang yang melihat unggahannya, juga berapa jumlah like yang di dapat. Jika aktivitas tersebut mendapat banyak pujian maka secara psikologis akan meningkatkan self-esteem, di sisi lain berdampak pada status sosial yang diterima. Kedua, melalui aksesoris tas ransel Gold's Gym. Ketika keluar dari dari Gold's Gym, member masih bisa menunjukkan kebiasaan konsumsi waktu luangnya dengan sekedar membawa aksesoris Gold's Gym atau menggunakannya ke dalam aktivitas yang lain seperti ke kampus. Sehingga mampu membantu untuk menunjukkan aktivitas konsumsi waktu luangnya ke ranah publik serta menunjukkan bahwa ia pantas untuk disegani karena kebiasaan konsumsi waktu luangnya. Konsumsi merupakan sarana untuk melakukan kegiatan lanjutan, dan bukan konsumsi yang diperlukan, hal tersebut hanya sebagai tanda kecakapan dan penghasilan tambahan bagi derajat manusia; barang-barang sekunder menjadikan dirinya terhormat, terutama konsumsi hal-hal yang lebih diinginkan.Dengan demikian, media dan aksesoris dari pusat kebugaran menjadi simbol bagi member untuk melakukan konsumsi waktu luangnya. Perangkat tersebut semakin mendorong sekaligus menjaga rutinitas aktivitas waktu luang para member di tempat gym.

\section{Kesimpulan}

Dari penelitian ini dapat dilihat bahwa transformasi fitness sebagai gaya hidup tidak hanya memiliki konsekuensi pada berbagai aktifitas yang berkaitan dengan reproduksi bentuk tubuh ideal, tetapi juga menjadi representasi status sosial melalui berbagai simbol dan sarana pemanfaatan waktu luang. Media sosial menjadi aspek penting yang menunjang bagaimana esensi dari aktifitas tersebut tersampaikan kepada kelompok sosialnya. Upaya untuk diakui 
secara sosial yang berlebihan membuat para member mengalami penyimpangan realitas tentang diri sendiri, melebih-lebihkan penampilan yang berkonsekuensi pada menurunnya self-esteem para member. Kekhawatiran, ketakutan, dan kecemasan untuk berhenti dari fitness yang bukan hanya terkait kebugaran dan masa otot, tetapi lebih pada penerimaan sosialnya menunjukkan esensi dari aktivitas ini telah mengalami pergeseran makna. Sehingga, wacana hidup sehat melalui aktivitas ngegym semestinya banyak dikaji secara kritis untuk lebih mengetahui kontruksi sosial yang terbangun dari aktivitas tersebut. Bagi masyarakat, gaya hidup sehat seharusnya dipahami secara esensial dan mempertimbangkan berbagai aspek, termasuk finansial sehingga gaya hidup sehat yang diterapkan tidak berkosekuensi pada penurunan well-being seseorang. Misalnya dengan menjadi member di tempat-tempat fitness sederhana, atau memilih olahraga lain untuk menghindari eksploitasi simbol dari berbagai tempat yang membuat terjadinya penyimpangan realitas diri.

\section{Daftar Pustaka}

Andreasson, \& Johansson, T. (2014). The Fitness Revolution. Historical Transformations in the Global Gym and Fitness Culture. Sport Science Review, 23(3-4), 91-112. https://doi.org/10.2478/ssr-2014-0006

Chaney, D. (2006). Lifestayle, Sebuah Pengantar Komprehensif . Yogyakarta: Jalasutra.

Creswell, JW. (2002). Reseach Design: Qualitative, Quantitative, and Mixt Method Approach (Second Edition). London: Sage Publication.

Felipe, A. F., Henrique, F. R., \& Monteiro, L. (2012). Characteristics of Family Nucleus as Correlates of Regular Participation in Sports Among Adolescents. Public Health, 57(2), 431-435. https://doi.org/10.1007/s00038-010-0207-7

Fhiske, J. (2006). Memahami Budaya Populer. Yogyakarta: Jalasutra.

Frijters, P., \& Leigh, A. (2008). Materialism on The March : From Conspicuous Leisure to Conspicuous Consumption? The Journal of Socio - Economics, 37(5), 1937-1945. https://doi.org/10.1016/j.socec.2008.07.004

Giddens, A. (1991). Modernity and Self-Identity: Self and Society in the Late Modern Age. Cambridge: Polity Press.

Gurusinga. (2015). Opini Masyarakat terhadap Fitness Center sebagai Gaya Hidup. Studi Deskriptif opini pengunjung Celebrity Fitness Sun Plaza Medan. Laporan Penelitian. Universitas Sumatra Utara.

Indriyana, R. (2014). Studi Tentang Motivasi Berolahraga pada Wanita Anggota Pusat Kebugaran di Kota Surakarta. Skripsi. Universitas Negri Surakarta.

Jameson, F. (1991). Postmodernism or the Cultural Logic of Late Capitalism. London: Verso.

Johansson, T. (1994). Gendered Spaces : The Gym Culture and The Construction of Gender. Young, 4(3), 32-47.

Kurniasari, E. (2016). Hiperrealitas dalam Transformasi Eksistensi Pusat Kebugaran Menurut Jean Baudrillad (Studi Pada Sanggar Senam Yuli dan Formula Fitness dan Aerobic di 
Pangkalpinang. Skripsi. Universitas Bangka Belitung.

Lash, S., \& Urry, J. (1987). The End of Organized Capitalism. Cambridge: Polity Press.

Leary, M. R., \& Baumeister, R. F. (2000). The Nature and Function of Self-Esteem. Advences in Experimental Social Psychology, 32(2), 1-62.

Liokaftos, D. (2012). From ' Classical' To ' Freaky :' an Exploration of the Development of Dominant , Organised, Male. Disertasi. University of London.

Nelissen, R. M. A., \& Meijers, M. H. C. (2011). Social benefits of luxury brands as costly signals of wealth and status. Evolution and Human Behavior, 32(5), 343-355. https://doi.org/10.1016/j.evolhumbehav.2010.12.002

Panigoro. (2013). Pengaruh Lifestyle Terhadap Keputusan Pembelian Menjadi Member Gold's Gym. Skripsi. Universitas Pendidikan Indonesia.

Piliang, Y. A. (2011). yang Dilipat: Tamasya Melampaui Batas-Batas Kebudayaan. Bandung: Matahari.

Sassatelli, R. (2016). Healthy Cities and Instrumental Leisure: The Paradox of Fitness Gyms as Urban Phenomena. Modern Italy, 20(3), 237-249. https://doi.org/10.1080/ 13532944.2015.1065239

Stempel, C. (2000). Sport, Social Class, and Cultural Capital: Building on Bourdieu and His Critics. https://osf.io/preprints/5np83/

Torkildsen, G. (1992). Leisure and Recreation Managemen. London: E \& FN SPON.

Trigg, A. B. (2016). Veblen, Bourdieu , and Conspicuous Consumption. Journal of economic issues, 35(1), 99-115. https://doi.org/10.1080/00213624.2001.11506342

Varul, M. Z. (2006). Waste, Industry, and Romantic Leisure Veblen's Theory of Recognition. 9(1), 103-117. https://doi.org/10.1177/1368431006060465

Veblen, T. (1994). The Theory of The Leisure Class. New York: The Modern Library.

Wheaton, B. (2003). Lifestyle sport magazines and the discourses of sporting masculinity. UK: Blackwell Publishing Ltd.

Wijayanti, K. (2009). Fenomena Pusat Kebugaran dalam Perkembangan Kota. Tesis Universitas Indonesia. 